\section{Solid om kognitiv terapi}

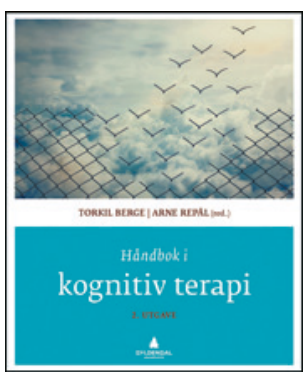

Torkil Berge, Arne Repål, red.

Håndbok i kognitiv terapi

2. utg. 484 S, tab, ill. Oslo: Gyldendal

Akademisk, 2015. Pris NOK 849

ISBN 978-82-05-45843-7

Kognitiv terapi har etter hvert fått stor utbredelse også i Norge, og et viktig element $\mathrm{i}$ å bygge opp et nasjonalt fagmiljø er lage fagbøker på norsk. Torkil Berge og Arne Repål har vært sentrale aktører i dette arbeidet. Deres siste bidrag er Håndbok $i$ kognitiv terapi, som nå kommer i andre utgave.

Boken er delt inn i fire deler med til sammen 28 kapitler. I første del omtales grunnelementene, og her inngår også et kapittel om brukerperspektivet. I hoveddelen beskrives kognitiv terapi ved 16 vanlige psykiske lidelser, i tillegg til ved langvarige smerter, søvnvansker og vedvarende utmattelse. Del tre omhandler kognitiv terapi anvendt i allmennpraksis, som miljøterapi og som selvhjelp, mens den siste delen omhandler følelsesfokusert og jobbfokusert kognitiv terapi.

Siden forrige utgave er kapitler som omtaler bruk av tester og kartleggingsskjemaer, behandling av barn og ungdom, par og familier, fysisk aktivitet og organisasjon og ledelse tatt ut. Det har kommet til et større introduksjonskapittel, i tillegg til kapitler om brukermedvirkning og jobbmestrende oppfølging. Boken er nå mer rendyrket som håndbok i individuell kognitiv terapi for voksne, som er det vanligste bruksområdet. Den fremstår nå som ganske komplett og dekkende for fagfeltet.

Denne utgivelsen er resultatet av en imponerende dugnadsinnsats. Det har utviklet seg flere solide fagmiljøer i Norge omkring kognitiv terapi, både klinisk og forskningsmessig, og de fleste av de sentrale aktørene er representert. Boken inneholder informasjon om både teoretisk forståelse og empirisk grunnlag, og hovedvekten ligger på grundige beskrivelser av hvordan kognitiv terapi kan gjennomføres i praksis ved de vanligste formene for psykiske lidelser. Dette er teksten du kan slå opp i for å friske opp gammel kunnskap eller lære noe nytt om hvordan du kan gå frem, når du ønsker å tilby en pasient kognitiv terapi.

Redaktørene har lyktes i å få det store antallet medforfattere til å skrive på en konsistent måte, og teksten fremstår derfor som helhetlig. De enkelte kapitlene kan leses hver for seg, noe som er praktisk for en håndbok. Dette er ikke den første boken du kjøper når du skal sette deg inn i hva kognitiv terapi er. Til det er den for omfattende, og det finnes flere mindre omfangsrike alternativer. Men det er en svært nyttig og praktisk bok som jeg anbefaler for helsearbeidere fra ulike profesjoner som arbeider med kognitiv terapi.

Egil W. Martinsen

Overlege, Klinikk psykisk helse og avhengighet

Oslo universitetssykehus

\section{En gave til alle på helsestasjonen}

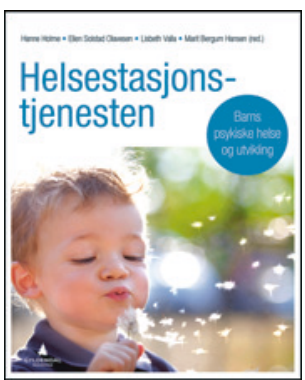

Hanne Holme, Ellen Solstad Olavesen, Lisbeth Valla et al, red. Helsestasjonstjenesten

Barns psykiske helse og utvikling. 554 s, tab, ill. Oslo: Gyldendal Akademiske, 2016. Pris NOK 799

ISBN 978-82-05-48629-4

Lenge har man i arbeidet på helsestasjonen hatt søkelys på hygiene og ernæring. Helsedirektoratets veiledere for virksomheten gir redskaper for å påvise avvik i vekst og mulighet for sykdom. Heldigvis er den somatiske helsetilstanden til barna i Norge svært god. Imidlertid er barns psykiske helse og mors og fars omsorgsevne i familienettverk som ofte rakner, i økende grad det store problemet. Omtrent ett av ti barn har psykiske vansker. For å kvalifisere oss på helsestasjonen til å forebygge og oppdage psykiske problemer er denne boken viktig.

Redaktørene arbeider på Regionsenter for barn og unges psykiske helse - RBUP Øst og Sør. De har gjort en god jobb med å samkjøre vel 41 forfattere med ulik bakgrunn, som helsesøstre, psykologer, leger, familieterapeuter, pedagoger og forskere, uten plagsomme gjentagelser. Boken er i solid paperback, enkelte kapitler er rikt illustrert også med fargebilder, det er oppsummerende rammer og tabeller, og til hvert kapittel er det referanseliste som muliggjør fordyping.

Kapitlene innledes med en beskrivelse av temaet som skal omtales. Det er ment at teksten skal leses fortløpende. Men dette er også en oppslagsbok, selv om jeg ønsker meg et fyldigere sakregister og oversikt over forkortelser som ikke alltid er forklart. Spredt i teksten er det kasuistikker som knytter seg godt til temaet. Disse kasuistikkene går rett til hjertet på leseren og gjør teksten levende.

Første tredel omhandler hjernens utvikling, epigenetikk, psykiske lidelser hos mor, tilknytningsteori, trygghetssirkel, det sosiale spedbarnet, foreldrerollen og betydningen av parforhold. I neste del omtaler man barnets temperament, stress og helse og mishandling. Her er to velskrevne kapitler om det krysskulturelle møtet og om minoritetshelse. Videre omtales fosterbarn, adoptivbarn, overvekt, rus og selvregulering hos spedbarnet. I siste del får vi informasjon om kommunikasjonsredskaper: hvordan aktivisere foreldrene, triangulerte samtaler, støttesamtaler, motiverende intervju og samtaler om bekymring. Til slutt omtales blant annet redskaper til bruk ved barseldepresjon, hjemmebesøk, familieveiledning og samspillsveiledning for foreldre og barn.

Boken vil interessere både allmennleger, barneleger, medisinstudenter, helsesøstre, sykepleiere på barneavdelinger, fysioterapeuter, psykologistudenter og psykologer som arbeider med barn. Løp og kjøp!

\section{Per Lagerløv}

Barnelege, St. Hanshaugen helsestasjon Oslo 